\title{
Supervisor Mentoring: Does a Female Manager Make a Difference?
}

\author{
M. Lee Williams, Ph.D. \\ Professor in the Department of Speech Communication \\ Southwest Texas State University, San Marcos, TX 78666 \\ Office Telephone: 512-245-3127 \\ FAX: 512-245-3138 \\ E-mail: mw02@swt.edu
}

Victoria Nevin Locke

Research Associate at The Psychological Corporation, San Antonio, TX

Paper Presented at the Institute for Behavioral and Applied Management (IBAM) conference, Annapolis, MD, November 4-6, 1999. Best Paper in Division I, Human Resources Management. 


\title{
Supervisor Mentoring: Does a Female Manager Make a Difference?
}

\author{
Abstract \\ Research investigating the management styles of male and female supervisors is mixed. In \\ an effort to clarify this research, the present study examined the interaction effect of gender of \\ supervisor and gender of subordinate on perceived mentoring. Results revealed the least amount of \\ mentoring occurred between female supervisors and female subordinates, but the greatest mentoring \\ took place between female supervisors and male subordinates. Results were explained in terms of \\ managerial experience and the double-bind of female managers. These findings challenge the \\ traditional advice that female subordinates should seek female supervisors.
}




\section{Supervisor Mentoring: Does a Female Manager Make a Difference?}

Mentoring, whether it be formal or informal, is a common practice in organizations today. In this dyadic relationship an older, more experienced member of the organization helps the younger employee learn to navigate in the workplace (Kram, 1983). Even though considerable research has investigated mentoring, very few studies have focused on the amount and type of mentoring provided by supervisors (Burke, McKenna \& McKeen, 1991). In addition, virtually no research has explored the nature of supervisor mentoring in same- and cross-gender supervisor-subordinate relationships. Therefore, the purpose of this paper is to explore research investigating supervisor mentoring as well as to test hypotheses addressing the kinds of mentoring provided by male and female supervisors to male and female subordinates.

This research is of value for three primary reasons. First, as indicated above, research has not considered the relationship between supervisor mentoring and gender combinations. This is an unexplored area of inquiry. Second, the results of this investigation should expand the already rich body of literature on mentoring, supervisor-subordinate relationships, and gender. While understanding has been gained in these separate areas, efforts to integrate the varying theoretical frameworks has been limited. New insights can be gained from synthesizing this literature and providing empirical testing. Finally, this study is of value for a very practical reason. Since women now comprise over $46 \%$ of the workforce (Bureau of Labor Statistics, 1998), it is important that we better understand the dynamics of gender, managerial styles, and employee perceptions. While some men find it difficult to work under the supervision of a female (Fairhurst, 1993), some women are uncomfortable supervising men. It is important to discover if these cross-gender situations impact the type of mentoring provided. As the work place becomes more diverse and complex, organizations need to anticipate problem areas and develop strategies for managing these complexities. 


\section{Review of Literature}

Mentoring

The unique characteristics of mentoring clearly establish the relationship as interpersonal (Kalbfleisch \& Davies, 1993). The mentor guides, counsels, and encourages the younger person, known as a protégé. Within the mentoring relationship, there are stages of coming together and coming apart, and feelings of intimacy may occur (Kram, 1983). Mentoring combines aspects of a work relationship as well as a personal relationship.

The mentor provides both career development and psychosocial support (Kram, 1983). The career development function includes sponsorship, visibility to others, protection, and offers of challenging assignments. The psychosocial function enhances a protégé's feeling of competence and sense of identity in the organization. From these two types of support, the protégé learns increased self confidence, ways of dealing with people, self insight, ways to approach problems, and an increased understanding of the organization (Burke, 1984). Furthermore, research indicates protégés enjoy the additional benefits of having greater job satisfaction (Mobley, Jaret, Marsh \& Lim, 1994; Riley \& Wrench, 1985), being promoted more often (Whitely, Dougherty, \& Dreher, 1991; Dreher \& Ash, 1990; Henderson, 1985), attaining an executive position at a younger age (Henderson, 1985), and receiving greater total compensation, including salary, bonuses, and benefits (Whitely, Dougherty, \& Dreher, 1991; Dreher \& Ash, 1990; Henderson, 1985).

Mentors can also benefit from the relationship. They find internal satisfaction from knowing they have made a positive impact on a younger person. Mentors also receive recognition within the organization from colleagues for successfully developing younger talent (Kram \& Isabella, 1985). On the downside, however, mentors may feel rivalrous and threatened by a protégé's growth and development (Kram, 1983). Lack of recognition can also be a problem. In a survey of public managers, $47 \%$ of those that thought of themselves as having been a mentor were not identified as such by their protégés (Henderson, 1985).

Research indicates that mentoring tends to occur in naturally hierarchical relationships (Burke, 1984). Burke, McKeen, \& McKenna (1993) found that approximately one-half of mentoring relationships occur within the protégé's hierarchical line of responsibility. Tepper (1995) 
showed that while $30 \%$ of employees in his study had a mentoring relationship with their supervisor, $18.5 \%$ of those were informal, and only $11.5 \%$ were formal. Findings also indicate that managers offer both protégés and nonprotégé subordinates career support (i.e., provide feedback, career planning, teaching, sponsorship); however, managers offer protégés more psychosocial support (Burke, McKenna \& McKeen, 1991). Protégés are perceived as being more promotable and more similar to the mentor. Managers are also more likely to confide in a protégé than a typical subordinate.

\section{$\underline{\text { Supervisor-Subordinate Communication }}$}

The quality of the supervisor-subordinate relationship is of vital importance to the employee as well as the organization. It is the primary relationship articulated by the organization (ShockleyZalabak, 1988), and structurally it is the most important communication link in the organization (Downs, Clampitt, \& Pfeiffer, 1988). Group meetings and top executives are desirable sources of information, but employees identify the immediate supervisor as the most preferred source of information (Foehrenback \& Goldfarb, 1990). In addition, employees indicate the immediate supervisor is the primary source for actually receiving information (Foehrenback \& Goldfarb, 1990).

Major reviews of supervisor-subordinate communication have helped synthesize the research findings for this vital dimension of organizational life. Jablin (1979) classified the literature into nine categories. He explored areas such as interaction patterns, openness in communication, upward distortion of information, the gap in understanding between supervisors and subordinates, supervisor feedback, and the communication qualities of effective versus ineffective supervisors. Updates to this research were provided by Jablin (1985) and Dansereau and Markham (1987). The most recent update by Jablin and Krone (1994) added the component of social support.

Social support is the communication between people that helps, comforts, cares for, and aids one or both persons (Albrecht \& Adelman, 1987). This unique form of human contact reduces uncertainty, provides a sense of personal control, and creates a stronger bond between the participants. Social support can serve as a buffer to shield the negative consequences of stress brought on by organizational factors such as role ambiguity, work overload, and job uncertainty (Cohen \& Wills, 1985). The most consistent finding in the social support research investigating 
organizations is that the immediate supervisor is the person most likely to provide this support and thus reduce employee stress (Anderson, 1991; Fenlason \& Beehr, 1994; Fisher, 1985; JonesJohnson \& Johnson, 1992; Ray, 1987; Ray \& Miller, 1991).

\section{Gender and Management}

Since the 1960s and 1970s when women began to enter the workforce en masse, researchers have sought to determine whether male and female managers have different styles or exhibit alternative patterns of communication. The results of that research have produced a variety of conflicting findings.

Powell (1990) reviewed the literature on gender differences in managerial behavior and concluded there were no differences in task-oriented behavior, people-oriented behavior, and subordinates' responses to actual managers. Eagly and Johnson (1990) reported that males and females were rated as equally effective by their subordinates. These findings would lead one to conclude that either gender has a trivial, almost inconsequential influence on behavior (Daniels, Spiker, \& Papa, 1997), or female managers over time reject the feminine stereotype and adapt to the male-dominated corporate culture (Berryman-Fink, 1997).

Other research, however, identifies gender differences. Witherspoon (1997) reviewed the leadership literature and noted several key differences between male and female managers. Men assume more task roles, give more opinions, are argumentative, and do not disclose personal information. Men tend to take over decision-making discussions, and criticize the opinions and ideas of other people. Conversely, women assume nurturing roles, interrupt for clarification, are more disclosive about information, and more supportive of other speakers. Women also try to avoid conflict by seeking compromises and talking through problems (Witherspoon, 1997).

Some contend that these differences between male and female managers create a female advantage in today's organizations (Helgesen, 1990). Because young girls are socialized to be cooperative, understanding, supportive, interpersonally sensitive, and flexible, they are more inclined to develop different managerial styles when they grow up and assume leadership positions in organizations (Helgesen, 1990). Furthermore, these traditional "feminine qualities" are more in line with contemporary organizations which value sharing information, collective decision-making, 
developing relationships, empowering others, and resolving conflict in nonconfrontational ways.

Some research investigating gender differences in organizational conflict has found that women were less competitive, more accommodating, more willing to share power, and more willing to discuss divergent viewpoints than men (Burrell, Buzzanell, and McMillan (1992). Korabik, Baril, and Watson (1993) noted gender differences in conflict management styles were present only in less experienced female managers. These women rated themselves as more obliging and compromising than did men. There were, however, no differences between male and female managers with experience. These findings seem to indicate that less experienced female managers exhibit more traditional feminine behavior acquired from socialization earlier in life, while more experienced female managers temper these feminine attributes and adopt more masculine qualities.

Another line of research investigating gender differences in management takes the position that men and women can learn from each other's unique leadership qualities, and the most desirable type of management is one which is androgynous (Maier, 1992). The most effective management style is the one that captures the best of both. According to this approach, men can learn from women, and women can learn from men.

Hypotheses

Some studies have sought to integrate various elements of research investigating mentoring, supervisor-subordinate communication, and gender differences in managers. While research from the 1970s and early 1980s indicated men were more likely to be mentored than women (Cook, 1979; Hall \& Sandler, 1983), more recent research has shown women are just as likely to be mentored as men (Mobley, Jaret, Marsh, \& Lim, 1994; Ragins \& Cotton, 1991). However, women perceive more barriers in acquiring a mentor (Ragins \& Cotton, 1991). These barriers include restricted access to potential mentors (i.e., senior executives), the perception that mentors were unwilling to enter into a relationship with them, and the feeling that other people would disapprove of the relationship, or misconstrue it as being sexual rather than professional (Ragins \& Cotton, 1991). Some research shows that mentors provide more psychosocial functions to women than men (Burke, McKeen \& McKenna, 1993), women managers mentor more women than men (Ragins \& Scandura, 1994), and women prefer female mentors (Kram, 1985). In addition, research indicates women 
often feel more isolated in the organization, and feel like they receive less mentoring from their immediate supervisor (Goh, 1991).

One limitation of much of the supervisor-subordinate research is that it has focused on gender primarily as a main effect. Studies have looked at the impact of the gender of the manager or the gender of the subordinate, but rarely have they investigated the same- or cross-gender combinations (i.e., an interaction effect). In particular, the nature of the relationship between a male subordinate with a female supervisor is not well understood. The main reason for limited research in this area is because fewer women are in upper-levels of management, especially in male-dominated industries (Noe, 1988).

Therefore, in an effort to better understand the role of gender in supervisor-subordinate mentoring relationships, the present study investigated gender as an interacting variable. The research question guiding the investigation was:

RQ: Do female subordinates with female supervisors receive more mentoring than other gender combinations of supervisors and subordinates?

Since prior research indicates women tend to be more relationship-oriented (Fairhurst, 1993), and since mentors provide more psychosocial functions to women than men (Burke, McKeen \& McKenna, 1993) it is expected that female managers will have greater empathy with female subordinates and thus provide more mentoring and social support to female subordinates than male subordinates. The following hypotheses are presented for testing:

H1: Female subordinates with female supervisors will receive significantly more mentoring than female subordinates with male supervisors.

H2: Female subordinates with female supervisors will receive significantly more mentoring than male subordinates with female supervisors.

\section{Method}

$\underline{\text { Instrumentation }}$

Supervisor mentoring was measured using a variation of the Mentoring and Communication Support Scale developed by Hill, Bahniuk, Dobos, and Rouner (1989). This instrument measures four factors: career mentoring, task support, coaching, and social support. The measure has a total 
of 15 items with Likert response options ranging from strongly agree (5) to strongly disagree (1). Career mentoring contains four items that identify the presence of a personal relationship (e.g., My immediate supervisor has shown a parental-like interest in me and my career). Task support contains four items that represent a reciprocal, collaborative relationship focused on sharing and exchanging work assignments and ideas (e.g., I work jointly on major projects or cases with my immediate supervisor). Coaching contains three items that focus on teaching the rules, goals, and politics of the organization (e.g., My immediate supervisor has coached me about office politics). Social support contains four items that measure a reciprocal friendship focused on sharing and exchanging personal problems and confidences (e.g., My immediate supervisor and I are friends as well as coworkers).

Reliability of the scale ranges from .75 to .89 for managers and from .76 to .85 for the general population (Hill, Bahniuk, \& Dobos, 1989). Reliability of the sub-factors was confirmed in a separate study. Among a sample of managers, the four factors of task support, coaching, career support and social support had alphas of $.89, .85, .75$, and .75 respectively (Dobos, Bahniuk, \& Hill, 1991). Criterion validity is evident, as the four factors correlate positively with satisfaction, promotions, and fast-track mobility (Hill, Bahniuk, \& Dobos, 1989).

The measure used in this analysis was slightly modified from the original version. Items which originally focused on coworker collegial support were rephrased to indicate supervisory collegial support. Other items which asked if someone of a higher rank had provided support were also rephrased to indicate supervisory support. With these modifications, all 15 items evaluated subordinates' perceptions of supervisor mentoring, not mentoring in general.

The questionnaire employed in the present study also asked respondents to complete an open-ended item. Subjects recalled a communication experience when support from his/her immediate supervisor was especially important. Relating communication experiences allowed subjects to reveal information that otherwise would be missed by a Likert scale. This rich, qualitative data also is invaluable when interpreting data from questionnaires (Downs, 1988).

\section{$\underline{\text { Respondents }}$}

Questionnaires were administered to employees of two metropolitan daily newspapers in the southwestern United States. The two newspapers are in the same state, approximately 80 miles 
apart, with a similar readership. These organizations were selected because of the nature of their business and employees. They are information-intensive, deadline-driven organizations, with many upwardly mobile employees. Many entry-level jobs require a college degree. Both organizations have relatively equal numbers of male and female employees, as well as male and female supervisors.

Prior to data collection, a liaison in the human resources departments of the two organizations informed employees they would be asked to participate in a study. Anonymity and voluntary participation were emphasized. Employees completed the supervisor mentoring questionnaire and answered other demographic questions. Upon completion, questionnaires were placed in a drop box located in the employees' work area.

$\underline{\text { Factor Analysis }}$

The revised version of the Mentoring and Communication Support Scale used in the present study was submitted to a confirmatory factor analysis with varimax rotation. Four guidelines for selection of factors were used. Each factor needed to have an eigenvalue of 1.0 or greater, each item needed to load at least .60 on one factor (but no higher than .40 on any other factor), and at least three items needed to load on a factor. Finally, each factor needed to have a reliability of .70 or greater. These criteria are typically used in factor analysis research (Smith, 1988).

Three factors with an eigenvalue greater than 1.0 were produced. The coaching factor contained three items and explained $27 \%$ of the variance (Cronbach alpha $=.85)$. Collegial social contained four items and explained $20.2 \%$ of the variance (Cronbach alpha $=.82$ ). Both factors were identical to those on the original scale by Hill, Bahniuk and Dobos (1989). A third factor, titled task mentoring, contained six task mentoring and career mentoring items from the original scale by Hill, Bahniuk and Dobos (1989). This factor explained 19.1\% of the variance (Cronbach alpha $=.88$ ). Two items which were included in the career mentoring factor of the original scale did not load at .60 or greater on any factor; therefore, these items were eliminated from the analysis.

There are several explanations why the confirmatory factor analysis produced three factors instead of the four in the original scale. The primary explanation is that the scale was revised. In the original scale, the career mentoring items were worded to state that "someone higher up" had 
provided the support. The scale used in this research changed "someone higher up" to "my immediate supervisor." Since this research was geared towards communication with the immediate supervisor, it is likely that the subjects were not able to make the distinction between career and task items. Also, respondents may not have viewed their immediate supervisor as a primary source for career mentoring.

\section{$\underline{\text { Design and Statistical Analysis }}$}

Separate $2 \times 2$ ANOVAs (supervisor gender $\mathrm{x}$ subordinate gender) were used to assess the interaction effect of same- and cross-gender relationships on mentoring. The dependent measures for mentoring were task mentoring, coaching, and collegial social. Individual subordinate responses were used as the unit of analysis. Since most subjects were in non-supervisory positions, the sample is ideal for studying female supervisors, as the vast majority of women in supervisory positions are middle or lower-level managers (Andrews \& Herschel, 1996).

\section{Results}

\section{Demographics}

One-hundred thirty-six questionnaires were collected in the first organization. Sixty-six were collected in the second organization; however, two were eliminated because the respondents left most of the items incomplete. Therefore, a total of two-hundred responses were used in the final analysis. The majority of the subjects (70\%) were between the ages of 25-44 and were in non-supervisory positions $(78 \%)$. Slightly more females $(52 \%)$ than males $(48 \%)$ completed the questionnaire. Fiftyseven percent had a male supervisor, and $41 \%$ had a female supervisor. Sixty-four percent of the total sample had worked for their immediate supervisor two years or less. The majority of the subjects were Caucasians (61\%), followed by Hispanics (27\%), African-Americans (7\%), Asians (2\%), and no response/other (3\%).

\section{Testing of Research Hypotheses}

The first hypothesis predicted that female subordinates with female supervisors would receive more mentoring than female subordinates with male supervisors. Hypothesis Two predicted that female subordinates with female supervisors would receive more mentoring than male subordinates with female supervisors. The $2 \times 2$ interaction effects for the three dependent variables 
(i.e., task mentoring, coaching, collegial social) were all significant, but they were not in the predicted direction. Therefore, both of the one-tailed hypotheses were disconfirmed.

Table 1 displays a pattern of findings opposite to those hypothesized. The modified LSD (Bonferroni) test was used in the post-hoc analyses. Results revealed female subordinates with female supervisors received significantly less task mentoring, $M=19.04$, than male subordinates with female supervisors, $\mathrm{M}=22.47$, and female subordinates with male supervisors, $\mathrm{M}=21.98, \mathrm{~F}$ $(1,192)=9.43, \mathrm{p}<.002$. Female subordinates with female supervisors also received significantly less collegial social support, $M=10.14$, than male subordinates with female supervisors, $M=$ 12.41, and female subordinates with male supervisors, $\mathrm{M}=11.98, \mathrm{~F}(1,191)=8.20, \mathrm{p}<.005$. In addition, female subordinates with female supervisors received significantly less coaching, $\mathrm{M}=$ 7.26, than male subordinates with female supervisors, $M=9.47$, and female subordinates with male supervisors, $\mathrm{M}=9.48, \mathrm{~F}(1,192)=17.27, \mathrm{p}<.001$. The main effects for gender of supervisor and gender of subordinate were not significant for any of the three types of mentoring.

Table 1

Interaction Effects of Subordinate and Supervisor Gender for Mentoring

Collegial
$\mathrm{N} \quad$ Social $\quad$ Coaching $\quad \begin{gathered}\text { Task } \\ \text { Mentoring }\end{gathered}$

Male Subordinate/

$\begin{array}{lllll}\text { Male Supervisor } & 62 & 11.33 & 8.27 & 20.81\end{array}$

Female Subordinate/

Male Supervisor

$52 \quad 11.98 b \quad 9.48 b$

$21.98 \mathrm{~b}$

Male Subordinate/

Female Supervisor

$32 \quad 12.41 \mathrm{a} \quad 9.47 \mathrm{a}$

22.47 a

Female Subordinate/

Female Supervisor

\begin{tabular}{cccc}
50 & $10.14 \mathrm{ab}$ & \multicolumn{1}{c}{$7.26 \mathrm{ab}$} & $19.04 \mathrm{ab}$ \\
& $\mathrm{F}=8.20$ & $\mathrm{~F}=17.27$ & $\mathrm{~F}=9.43$ \\
$\mathrm{p}<.005$ & $\mathrm{p}<.001$ & $\mathrm{p}<.002$
\end{tabular}

ab -- modified LSD (Bonferroni) post-hoc analysis tests indicate means with common letters are significantly different $(\mathrm{p}<.05)$. 


\section{Discussion}

The hypotheses in this study predicted that female subordinates with female supervisors would perceive significantly more supervisory mentoring than other gender dyad combinations. Even though significant interactions emerged for each dimension of mentoring, the hypotheses were disconfirmed since findings were not in the predicted direction. Female subordinates with female supervisors perceived the least mentoring behavior. Not only do these results contradict the advice given to women that they need to acquire a female mentor (Ragins \& Cotton, 1993), they also contradict the mentoring research which indicates mentors provide more psychosocial functions to women than men (Burke, McKeen, \& McKenna, 1993).

There are several explanations which help clarify these mentoring results. In terms of the same-gender female relationship, many female supervisors appear to be in a double-bind when working with female subordinates. Cultural expectations are that women will act feminine, yet the workplace operates on masculine assumptions (Berryman-Fink, 1997). Good managers are seen as displaying masculine oriented behaviors such as competitiveness, aggression, and independence (Berryman-Fink, 1997). Often women have to be tough in order to rise into the managerial ranks in a competitive industry. They have to change their communication style in an effort to adapt to male-dominated hierarchical organizations (Wood, 1997). As a result, they can become more direct and unresponsive to feelings, which provokes a negative evaluation (Wood, 1997).

These changes from a feminine to more masculine style are incongruent with sex role expectations (Lamude \& Daniels, 1990). This incongruence appears to be especially problematic for female subordinates who anticipate that a female supervisor will empathize more with their personal and professional problems. Perhaps when female subordinates become aware of this contravention of expectations, they are surprised and disappointed. In addition, females, more so than males, communicate with their superiors for affection and relaxation (Anderson \& Martin, 1995). When female supervisors do not satisfy these motives for communication, female subordinates feel violated.

The qualitative data gathered from female subordinates with female supervisors support the double-bind explanation. Respondents were asked to report critical incidents with their supervisor. 
One question asked the subject to recall an incident when support from her immediate supervisor was especially important. Positive critical incidents often centered around work-related issues where the supervisor made a tough decision. For example, one commented:

I was having difficulty with a co-worker who singled me out for mistreatment. At first (my supervisor) was too low key. When a much more disruptive confrontation occurred, my supervisor took a stronger stand with my co-worker and things are much improved ... (she) is not afraid to get tough when the situation calls for it.

Another indicated:

A writer whom I supervised absolutely could not meet deadlines. I tried various approaches, but the end result was always the same--missed deadlines. My supervisor took a "hard-line" and insisted that meeting deadlines was second only to accuracy in our work ... it was what I would have expected in this case . . . only my supervisor could handle this situation because I do not have hiring/firing power, and that is what was needed in this instance.

In addition to the positive critical incidents, a variety of respondents commented on negative incidents centered around their supervisor's get-tough attitude. Many of these were on a more personal level, however. One person indicated:

After I came back from maternity leave, I asked my supervisor if I could express milk once a day ... Four months later, I was called on the carpet because I was "still" expressing milk even though company policy permits a 15-minute paid break ... no dialogue occurred; no reasons were cited--and this is very typical.

Others express problems with their female supervisor with comments like the following:

"It's too depressing. I can't remember being given support from my supervisor. She never has a good word for what I do." "There have been times a discussion would come up (where) we/I disagree; she wouldn't say anything to me for days," and "My supervisor can't take criticism or suggestions. She protects herself first." These comments suggest that female employees might be anticipating a more understanding relationship with their female supervisor, but feel upset when these expectations are not met.

Another explanation for these results is that women managers communicate differently with female subordinates because of their ambivalence about being identified with other women and with feminine values. Leadership is typically identified with masculine communication styles such as assertiveness, independence and confidence, while feminine communication styles are associated with more subordinate roles (Wood, 1997). Female managers may be harder on female 
subordinates in an effort to distance themselves from being identified with other women. For example, during conflict, female managers use more forceful tactics with female subordinates than they do with male subordinates (Euwema \& van de Vliert, 1994). In concurrence with this explanation, Ashcraft and Pacanowsky (1996) found that women in a female-dominated office tried to distance themselves from the "femaleness" in the organization and instead claimed to prefer male coworkers and masculine standards.

The results of this study may also be explained by certain limitations. The sample of respondents included a specialized group of professionals. This could have created biases and limited generalizability of the results. The subjects were relatively young, with $70 \%$ between the ages of 25 and 44. The nature of the organizations was androgynous, with relatively equal numbers of male and female employees. Perhaps gender differences and stereotypes were not as prevalent as may occur in other, more traditionally male-dominated industries. The newspaper business may be quite different from organizations in more industrial settings. People need to be aggressive, literate, and have strong persuasive abilities in order to succeed in an information intensive environment. It is possible that these qualities are more important for success than gender.

Another limitation concerns the perceptual nature of the instruments. The results are based on the subordinates' perceptions only. Perhaps female supervisors are not actually giving their female subordinates less mentoring, but when female subordinates' expectations are violated, they perceive themselves being mentored less than male subordinates. Research directed toward assessing supervisor behavior would help clarify differences between subordinate perceptions and actual behavior.

The results of this investigation raise significant questions for practitioners as well as academicians. Mentoring is crucial to the development of new employees, and supervisors play a vital role in this process. If indeed female supervisors provide significantly less mentoring to female subordinates, many organizations need to rethink their mentoring programs. In addition, female subordinates might need to reconsider who they approach for mentoring. Scholars might also need to reconceive how they approach supervisor and mentoring research. Perhaps more 
meaningful results would emerge if there was more focus on the interaction of supervisorsubordinate gender and less attention given to comparing female management styles to male management styles. Additional research is needed to help clarify these issues. 


\section{References}

Albrecht, T. L., \& Adelman, M. B. (1987). Communicating social support: A theoretical perspective. In T. L. Albrecht, M. B. Adelman, and Associates (Eds.), Communicating social support (pp. 13-39). Newbury Park, CA: Sage Publications.

Anderson, J. G. (1991). Stress and burnout amoung nurses: A social network approach. Journal of Social Behavior and Personality, 6, 251-272.

Anderson, C. M., \& Martin, M. M. (1995). Why employees speak to coworkers and bosses: Motives, gender, and organizational satisfaction. Journal of Business Communication, 32, 249-265.

Andrews, P. H., \& Herschel, R. T. (1996). Organizational communication: Empowerment in a technological society. Boston: Houghton Mifflin.

Ashcraft, K. L., \& Pacanowsky, M. E. (1996). A woman's worst enemy: Reflections on a narrative of organizational life and female identity. Journal of Applied Communication Research, 24, 217-239.

Berryman-Fink, C. (1997). Gender issues: Management style, mobility and harassment. In P. Y. Byers (Ed)., Organizational communication: Theory and behavior (pp. 259-283). Boston: Allyn and Bacon.

Bureau of Labor Statistics. (1998). Civilian labor force by sex, age, race, and Hispanic origin, 1986, 1996, and projected 2006. Retrieved April 20, 1999 from the World Wide Web: http://stats.bls.gov/ecopro.table1.htm 353-372.

Burke, R. J. (1984). Mentors in organizations. Group and Organization Studies, 9 ,

Burke, R. J., McKeen, C. A., \& McKenna, C. (1993). Correlates of mentoring in organizations: The mentor's perspective. Psychological Reports, 72, 883-896.

Burke, R. J., McKenna, C. S., \& McKeen, C. (1991). How do mentorships differ from typical supervisory relationships? Psychological Reports, 68, 459-466.

Burrell, N. A., Buzzanell, P. M., \& McMillan, J. (1992). Feminine tensions in conflict situations as revealed by metaphoric analyses. Management Communication Quarterly, 6, 115145.

Cohen, S., \& Wills, T. A. (1985). Stress, social support, and the buffer hypothesis. Psychological Bulletin, 98, 310-357.

Cook, M. F. (1979). Is the mentor relationship primarily a male experience? The Personnel Administrator, 24, 82-86.

Daniels, T. D., Spiker, B. K., \& Papa, M. J. (1997). Perspectives on organizational communication (4th ed.). Dubuque: Brown \& Benchmark.

Dansereau, F., \& Marham, S. E. (1987). Superior-subordinate communication: Multiple levels of analysis. In F. M. Jablin, L. L. Putnam, K. H. Roberts, \& L. W. Porter (Eds.), Handbook of organizational communication (pp. 343-388). Newbury Park, CA: Sage. 
Dobos, J., Bahniuk, M.H., \& Hill, S. E. K. (1991). Power-gaining communication strategies and career success. The Southern Communication Journal, 57, 35-48. Company.

Downs, C. W. (1988). Communication audits. Glenview, IL: Scott, Foresman and

Downs, C. W., Clampitt, P. G., \& Pfeiffer, A. L. (1988). Communication and organizational outcomes. In G. M. Goldhaber, \& G. A. Barnett (Eds.), Handbook of organizational communication (pp. 171-211). Norwood, NJ: Ablex.

Dreher, G. F., \& Ash, R. R. (1990). A comparative study of mentoring among men and women in managerial, professional, and technical positions. Journal of Applied Psychology, 5 , 539-546.

Eagly, A. H., \& Johnson, B. T. (1990). Gender and leadership style: A meta-analysis. Psychological Bulletin, 108, 233-256.

Euwema, M. C., \& van de Vliert, E. (1994). The influence of sex on managers' reactions in conflict with their subordinates. In A. Taylor, \& J. B. Miller (Eds.), Conflict and gender. Cresskill, NJ: Hampton Press, Inc.

Fairhurst, G. T. (1993). The leader-member exchange patterns of women leaders in industry: A discourse analysis. Communication Monographs, 60, 321-351.

Fenlason, K. J., \& Beehr, T. A. (1994). Social support and occupational stress: Effects of talking to others. Journal of Organizational Behavior, 15, 157-175.

Fisher, C. (1985). Social support and adjustment to work: A longitudinal study. Journal of Management, 11, 39-53.

Foehrenback, J., \& Goldfarb, S. (1990). Employee communication in the '90s: Greater expectations. Communication World, 7(6), 101-106.

Goh, S. C. (1991). Sex differences in perceptions of workstyle, career emphasis, supervisory mentoring behavior, and job satisfaction. Sex Roles, 24, 701-711.

Hall, R. M., \& Sandler, B. R. (1983). Academic mentoring for women students and faculty: A new look at an old way to get ahead. Washington, D.C.: Project on the status and education of women, 1-33.

Helgesen, S. (1990). The female advantage: Women's ways of leadership. New York: Doubleday.

Henderson, D., W. (1985). Enlightened mentoring: A characteristic of public management professionalism. Public Administration Review, 15, 857-863.

Hill, S. E. K., Bahniuk, M. H., \& Dobos, J. (1989). The impact of mentoring and collegial support on faculty success: An analysis of support behavior, information adequacy, and communication apprehension. Communication Education, 38, 15-33.

Hill, S. E. K., Bahniuk, M. H., Dobos, J., \& Rouner, D. (1989). Mentoring and other communication support in the academic setting. Group and Organization Studies, 14, 355-368.

Jablin, F. M. (1979). Superior-subordinate communication: The state of the art. Psychological Bulletin, 86, 1201-1222. 
Jablin, F. M. (1985). Task/work relationships: A life-span perspective. In M. L. Knapp, \& G. R. Miller (Eds.), Handbook of interpersonal communication (pp. 615-654). Newbury Park, CA: Sage Publications.

Jablin, F. M., \& Krone, K. J. (1994). Task/work relationships: A life-span perspective. In M. L. Knapp, \& G. R. Miller (Eds.), Handbook of interpersonal communication (2nd ed.) (pp. 621-675). Thousand Oaks, CA: Sage.

Jones-Johnson, G., \& Johnson, W. R. (1992). Subjective underemployment and psychosocial stress: The role of perceived social and supervisor support. Journal of Social Psychology, 132, 11-21.

Kalbfleisch, P. J., \& Davies, A. B. (1993). An interpersonal model for participation in mentoring relationships. Western Journal of Speech Communication, 57, 399-415.

Korabik, K., Baril, G. L., \& Watson, C. (1993). Managers conflict management style and leadership effectiveness: The moderating effects of gender. Sex Roles, 29, 405-420.

Kram, K. E. (1983). Phases of the mentor relationship. Academy of Management Journal, $\underline{26,} 608-625$.

Kram, K. E. (1985). Mentoring at work. Boston: Scott, Foreman, \& Co.

Kram, K., E., \& Isabella, L. A. (1985). Mentoring alternatives: The role of peer relationships in career development. Academy of Management Journal, 28, 110-132.

Lamude, K. G., \& Daniels, T. D. (1990). Mutual evaluations of communication competence in superior-subordinate relationships: Sex role incongruency and pro-male bias. Women's Studies in Communication, 13, 39-56.

Maier, M. (1992). Evolving paradigms of management in organizations: A gendered analysis. Journal of Management Systems, 4(1), 29-45.

Mobley, C. M., Jaret, C., Marsh, K., \& Lim, Y. Y. (1994). Mentoring, job satisfaction, gender, and the legal profession. Sex Roles, 31, 79-98.

Noe, R. A. (1988). Women and mentoring: A review and research agenda. Academy of Management Review, 13, 65-78.

Powell, G. N. (1990). One more time: Do female and male managers differ? Academy of Management Executive, 4, 68-75.

Ragins, B. R., \& Cotton, J. L. (1991). Easier said than done: Gender differences in perceived barriers to gaining a mentor. Academy of Management Journal, 34, 939-951.

Ragins, B. R., \& Cotton, J. L. (1993). Gender and willingness to mentor in organizations. Journal of Management, 19, 97-111.

Ragins, B. R., \& Scandura, T. A. (1994). Gender differences in expected outcomes of mentoring relationships. Academy of Management Journal, 37, 957-971.

Ray, E. B. (1987). Supportive relationships and occupational stress in the workplace. In T. L. Albrecht, \& M. B. Adelman (Eds.), Communicating social support, (pp. 172-191). Newbury Park, CA: Sage Publications. 
Ray, E. B, \& Miller, K. I. (1991). The influence of communication structure and social support on job stress. Management Communication Quarterly, 4, 506-527.

Riley, S., \& Wrench, D. (1985). Mentoring among women lawyers. Journal of Applied Social Psychololgy, 15, 374-386.

Shockley-Zalabak, P. (1988). Fundamentals of organizational communication. New York: Longman Inc.

Smith, M. J. (1988). Contemporary communication research methods. Belmont, CA: Wadsworth Publishing Company.

Tepper, B. J. (1995). Upward maintenance tactics in supervisory mentoring and nonmentoring relationships. Academy of Management Journal, 38, 1191-1205.

Whitely, W., Dougherty, T. W., \& Dreher, G. G. (1991). Relationship of career mentoring and socioeconimic origin to managers' and professionals' early career progress. Academy of Management Journal, 34, 331-151.

Witherspoon, P. D. (1997). Communicating leadership: An organizational perspective. Boston: Allyn \& Bacon.

Wood, J. T. (1997). Gendered lives: Communication, gender and culture. Belmont: Wadsworth Publishing. 